\title{
"Monitoring the financial security of the Ukrainian banking sector in the context of system-deterministic challenges"
}

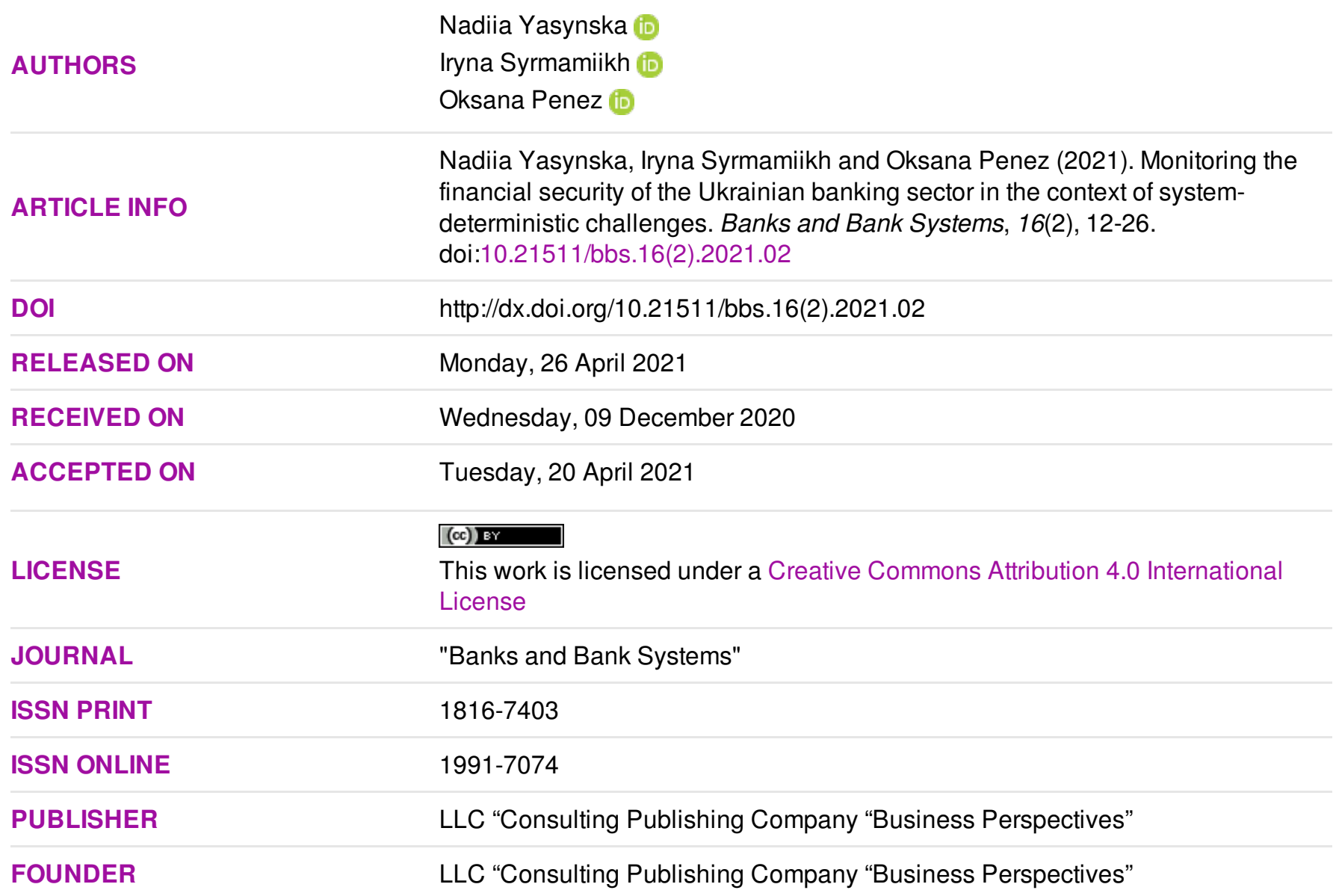

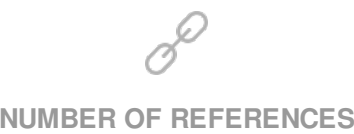

34

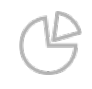

NUMBER OF FIGURES

2

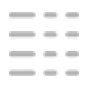

NUMBER OF TABLES

8

(C) The author(s) 2021. This publication is an open access article. 


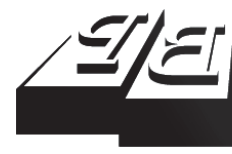

\section{BUSINESS PERSPECTIVES}

LLC "CPC "Business Perspectives" Hryhorii Skovoroda lane, 10, Sumy, 40022, Ukraine www.businessperspectives.org
Received on: $9^{\text {th }}$ of December, 2020 Accepted on: $20^{\text {th }}$ of April, 2021 Published on: $26^{\text {th }}$ of April, 2021

(C) Nadiia Yasynska, Iryna Syrmamiikh, Oksana Penez, 2021

Nadiia Yasynska, Doctor of Economics, Professor, Faculty of Economics, Department of Finance and Accounting, Donetsk State University of Management, Ukraine. (Corresponding author)

Iryna Syrmamiikh, Ph.D. (Economics), Associate Professor, Head of the Department of Computer Science, Faculty of Economics, Donetsk State University of Management, Ukraine.

Oksana Penez, Senior Scientific Associate, Faculty of Economics, Department of Finance and Accounting, Donetsk State University of Management, Ukraine. SECURITY OF THE UKRAINIAN BANKING SECTOR IN THE CONTEXT OF SYSTEM-
DETERMINISTIC CHALLENGES

\begin{abstract}
The development of the financial market and the transformation of the banking sector create a need for diagnostics of its financial security. This study is aimed at determining the level of the Ukrainian banking sector financial security in the event of decapitalization of the national economy. The paper uses multicomponent and behavioral analysis methods. The empirical study is based on Ukrainian data for 37 indicators by three components (for multicomponent analysis) and 23 indicators (for behavioral analysis). The study presents an improved algorithm for monitoring the level of Ukrainian banking sector's financial security based on the calculation of the integral indicator. Only the system of "Financial results" indicators as the most significant component has relative independence from the other two components ("Financial stability" and "Macroeconomic stability"). According to assessments, in 2008-2017 Ukrainian banking sector's financial security was $0,485-0,539$; and in 2018 it became 0,626 . The behavioral analysis of the partial integral indicator of the "Financial stability" component with the withdrawn assets located in offshore jurisdictions revealed the causal relation of the negative impact of capital outflow on the financial stability of the banking sector. This study has a practical value for determining the level of the banking sector financial security.
\end{abstract}

\title{
Keywords indicator, financial risks, rating, integral assessment, stimulant, bank assets, illegal export of capital
}

\section{JEL Classification $\quad$ G21, G28, G29}

\section{INTRODUCTION}

Systemic regulation of the banking sector is one of the most important tasks for Ukraine in the context of the need to overcome further crisis phenomena in the economy. In the current environment of the divergence of the financial sector over the real sector, the demands for quality information about its performance and the ability to make managerial decisions that provide the material basis for socio-economic growth are growing. In the context of the said divergence, banks are oriented towards implementing macroprudential and microprudential policy norms and lack the tools to solve their own tactical and strategic tasks. Under such divergence, banks are not aimed at maintaining the banking sector's financial stability as a whole.

The impact of current economic, organizational, and other changes on the-banking sector manifests itself in the fact that the disturbance of the equilibrium condition of the sector itself under their impact should to be correlated with its potential ability to return to a stable condition when solving problems of the economic system without being limited to servicing function only. The banking sector's ability to maintain a stable capacity under the conditions of unstable external 
environment, in particular, should be assured by decisions based on the results of the strategic analysis of macro-, meso-, and microenvironment. The strategic analysis results show show the identification of numerous factors of external influence and their grouping into the main areas of influence, as well as the determination of the effectiveness of their impact on the current activities of the banking sector.

Nevertheless, the loss of liquidity of economic agents raises the issue of banks' funding, and a diverse resource base is necessary for their sustainability. In a crisis, the search for long-term funding becomes crucial for the strategy of the banking sector's existence. Accordingly, the financial security of the banking sector is not limited to an individual bank; however, it is a causal element of analysis under systemdetermined challenges (capital outflow in the digitalization of banking services, money flows, and the decline in the level of solvency of banks' clients, etc.). In turn, these challenges are dynamic in an open economic system.

\section{LITERATURE REVIEW}

Determining the level of the banking sector's financial security is a matter of paramount importance, and it has been addressed and partly solved in numerous scientific developments and methodologies. This allows studying this problem based on and taking into account the existing materials, both already tested and still debatable.

To monitor the success of the banking sector, scientists and practitioners usually use two approaches such as ranking and rating banks and their risks in the national (regional) banking system or assessing the level of competitiveness and banks' compliance with national and international regulatory standards concerning their competitors.

Regarding the first group of researchers addressing ranking and rating banks' problems and their risks in the national (regional) banking system, the following should be noted. Berger and Humphrey (1997) apply parametric and nonparametric methods to a sample of 130 research units and 21 unique business practices to determine the level of efficiency of banking and parabank structures to confirm the variability of the approaches chosen to determine the performance of financial market entities. Aldasoro et al. (2020) contribute to the discussion by analyzing the operational and cyber risks of banks in 16 time periods with 70 sample units. The researchers confirm the need to improve the methods for analyzing the performance of banks and the introduction of Basel III. Siemiatkowski (2017) and Packer et al. (2011) propose to rank the level of economic internationalization based on calculating the taxonomic index of external financial security based on data from 11 independent factors for nine economies. These independent factors are based on liquid flows and the success of the financial economy. Aguayo et al. (2020) apply the ranking of countries by the level of digitalization of banking services to the study of methods for optimizing banks' risk management. The authors insist on the existence of an inverse correlation between operational risk and the bank capital, etc.

Wojewodzki et al. (2017) and Tarashev et al. (2011) examine banks' credit rating as a critical criterion in making financial decisions, reflecting the quantitative assessment of risks. In this case, the authors use econometric tools of statistical analysis, but their application is limited to banks' economy. Marković et al. (2020) and Stajić et al. (2020) study the objective ranking of banks and the real need for the formation of an adequate ranking model of the banking sector, which best assesses the quality of each bank and, as a result, provides a complete list of all ranked banks.

Karkovska (2018) and Snishchenko (2018) identify measures and components of systematic control of the external and internal environment of the Ukrainian banking sector financial security to identify and assess the impact of destabilizing factors and risks to its normal functioning. Subbotovich and Antropova (2013) emphasize the significant role and economic importance of banking security as a prerequisite for the stable national economy's development, indicators of banking security, problems of safety state regulation, the effectiveness of certain areas of banking activity, etc. Their research, propositions, and 
scientific publications are based on financial policy. They have practical significance and aim to balance the country's financial system and adapt it to global requirements. Gladkikh (2015), based on analytical data, suggests measures for the successful implementation of banking policy in the medium term to ensure macroeconomic stability in Ukraine.

Zachosova and Babina (2018) simulate the behavior of Ukrainian financial institutions' economic security in 2018 on the conjuncture of the financial market and the state financial security. At the same time, this paper lacks a methodology according to which the research is carried out. Monetary and financial stability in the coronavirus outbreak became the Tobias' research subject (2020). The assumption was made that if economic and financial conditions were to deteriorate further, policymakers could revert to the broader toolkit developed during the financial crisis.

Part of the research on the banking sector's financial security is devoted to clarifying and solving problems of banks' compliance with the requirements of state and international regulators. So, Obradović and Grbić (2015) analyze four indicators of financial intermediation development and unidirectional causality relationship between them. The authors investigate the situation with the financial deepening, which contributes to economic growth due to the advanced supply of new (updated) financial instruments.

At the same time, when agreeing that the banking sector is an open and dynamic system in the complex of financial relations, it is advisable to determine the banking sector's level of financial security, taking into account the lag of independent factors. Baranovsky (2004), Vasylchyshyn (2017), and Vlasyuk (2014) examine current monitoring methodologies, techniques and mechanisms for diagnosing the Ukrainian banking sector's financial security. The econometric approach to analyzing and monitoring the financial security of the banking sector studied in this paper is based on Goldberger (2011) and Dougherty (1991), who paid attention to the content of econometric analysis, and Greene (2011), who focused on the analysis of time series and the use of distributed lag models.
The IMF's experience in combating illicit financial flows and the financial sector assessment program (IMF, 2018) and research results of Herkenrath (2014) are considered in the paper. Herkenrath's research overview shows that illicit financial flows contribute to a decrease in the level of liquidity of centralized and decentralized finance, the financial stability of the economy, and the efficiency of the current tax system. The outflow of money from the country deprives banks of the surplus product from working with financial instruments. The information resources of the study were the Medium-Term Strategy of Public Debt Management for 2019-2022 (2019), official data of the State Treasury Service of Ukraine (2015-2020), the Ministry of Finance of Ukraine (2012, 2013, 2014), and the National Bank of Ukraine (2019, 2020, 2020a).

It has to be outlined that today there is no legally established norm on the Methodology for analyzing the financial security of the Ukrainian banking sector, based on the functioning of all parts of the country's financial system. Considering the Guidelines' norms for calculating the level of economic security of Ukraine (The Ministry of Economic Development and Trade of Ukraine, 2013), scientists calculate banking, as one of the components of financial security, according to only the banking system or several banks on a limited list of performance indicators. Thus, Gladkikh (2019) defined the integral index of banking security in 2013 and 2018 as "satisfactory" (values of 0.62 and 0.67 , respectively), and in 2014-2017 as "insecure" (values of $0.51 ; 0.53 ; 0.55,0.59$, respectively). Concurrently, it is understood that, on the one hand, the links of the financial system function in close interrelation, and, on the other hand, there is a fact of divergence of the financial sector over the real one. Accordingly, in the rapidly changing conditions of the external environment of functioning and universalization of banks, the seven methodologies proposed in the Methodological Recommendations and described above are not possible due to certain qualifications and assumptions in each case or are of an advisory nature. In this context, all of the above problems proved that the topic requires further development, which determined the subject of the study. 


\section{AIMS}

This study is aimed at monitoring the Ukrainian banking sector's financial security and identifying causal relationiships between the components of financial security in system-deterministic challenges.

\section{METHODS}

\subsection{Data selection for multicomponent analysis}

The described two scientific approaches to assessing the financial security of the country's banking sector's are based on the analysis of a multi-level system with dynamic data with the possible application of ranking or rating norms. Both the first and second cases use static data as of a specific date. Due to the dependence of the current state of the system on the previous period, economic indicators are usually autocorrelated. Therefore, regression with the required independent factors, which forms a vector of unknown dimensions, generates biased estimates of the lag structure (Millar et al., 2016; Vu et al., 2019). Accordingly, this feature should be taken into account when calculating the banking sector's level of financial security.

For multicomponent analysis, it is proposed to use the following data and analysis system. The most significant indicators and the indicators proposed to assess the Ukrainian banking sector's financial security comprehensively, and that should be consistently reduced to an integral indicator are divided into three groups, that is a three-component approach to determining groups of indicators is proposed.

Appendix A, Table A1 shows the system of indicators evaluating the Ukrainian banking sector's financial security. As will be proved below, this list is not exhaustive and can be supplemented depending on the depth and purpose of the study. The priority of the study is the analysis of indicators of Appendix A, Table A1 in dynamics. This approach to ensuring Ukrainian banking sector's financial security will provide an adequate assessment of the value of the integral indicator in dynamics. To achieve timely response to threats to the Ukrainian banking sector's financial security, a comprehensive assessment should be introduced, including three blocks such as determining the overall integral indicator, determining the most influential indicators, and monitoring the most critical indicators (Appendix A, Figure A1).

Appendix B shows the Performance systems of the "Financial results" component, indicators of the "Financial stability" component and the system of indicators of the "Macroeconomic stability" component.

All selected indicators (Appendix B) could be used to combine into one standard integral indicator, each value of the actual index is standardized. The system of indicators was standardized using the maximum and minimum values of each of the indicators for the period 2008-2018 (Appendix C):

for stimulants: $Z=\frac{a-x_{\min }}{x_{\max }-x_{\min }}$,

for destimulators: $Z=\frac{x_{\max }-x_{\min }}{x_{\max }-a}$,

where $a$ - the actual value of the indicator; $x_{\max }$ and $x_{\min }$ - the maximum and minimum value of the indicator in the aggregate.

It is assumed that specific indicators have the same impact on each component of the Ukrainian banking sector's financial security, and there is no need to determine the significance (weight) of each of the selected indicators. Then partial integral indicators for each component are calculated separately for each year as the average of standardized indicators:

$$
I R_{m}=\bar{Z}, i=1,2,3 .
$$

\subsection{Criteria for a qualitative assessment of the level of the Ukrainian banking sector financial security}

There are the following approaches to determining the threshold values of indicators:

- legislative, or the establishment of limit values of indicators at the level of legislation;

- analogue, or determination of threshold values by comparing the corresponding indica- 
tors with the values in countries with comparable macroeconomic indicators, international organizations' calculations; and

- expert assessments.

Table 1 presents the characteristic values of indicators of the components of the economic security of Ukraine for expert assessments.

Table 1. Criteria for a qualitative assessment of Ukrainian banking sector's financial security

Source: The Ministry of Economic Development and Trade of Ukraine (2013).

\begin{tabular}{|c|c|}
\hline Indicator value in intervals & Characteristic \\
\hline 0 & $\begin{array}{l}\text { Minimum or absolutely } \\
\text { dangerous level of security }\end{array}$ \\
\hline$(0-0.2]$ & Critical security level \\
\hline$(0.2-0.4]$ & Insecure security level \\
\hline$(0.4-0.6]$ & $\begin{array}{l}\text { Unsatisfactory level of } \\
\text { security }\end{array}$ \\
\hline$(0.6-0.8]$ & Satisfactory level of security \\
\hline$(0.8-1]$ & Optimal level of security \\
\hline
\end{tabular}

\section{RESULTS}

\subsection{Determination of the integral indicator}

Based on the integral indicators of each component, the level of the banking sector's financial security of the economy is calculated (Appendix C). Figure 1 shows a graphical interpretation of the results.

Appendix C shows that the level of the overall integral index ranges from 0.474 in 2012 to 0.626 in 2018. To quickly respond to adverse changes, one can determine the most critical indicators affecting the financial security of the Ukrainian banking sector.

Based on a comparative analysis of the paired correlation coefficients of the selected indicators and the overall integral indicator (Table 2), it can be seen that quite a few factors have a significant value.

Checking using Student's t-criterion for the significance of correlation coefficients at the level of $\alpha=$ $0.05\left(t_{c r i t}=2.26\right.$ - for a two-way critical area) made it possible to select indicators whose correlation coefficients significantly differ from zero with a probability of 0.95 , that is, correlate with the general integral index of Ukrainian banking sector's financial security (Table 3 ).

An analysis of the interconnections between a comprehensive assessment of the financial security of the banking sector and the selected indicators shows that the greatest threat may be posed by slow growth of total assets of banks, funds of business entities in bank accounts, gross loans

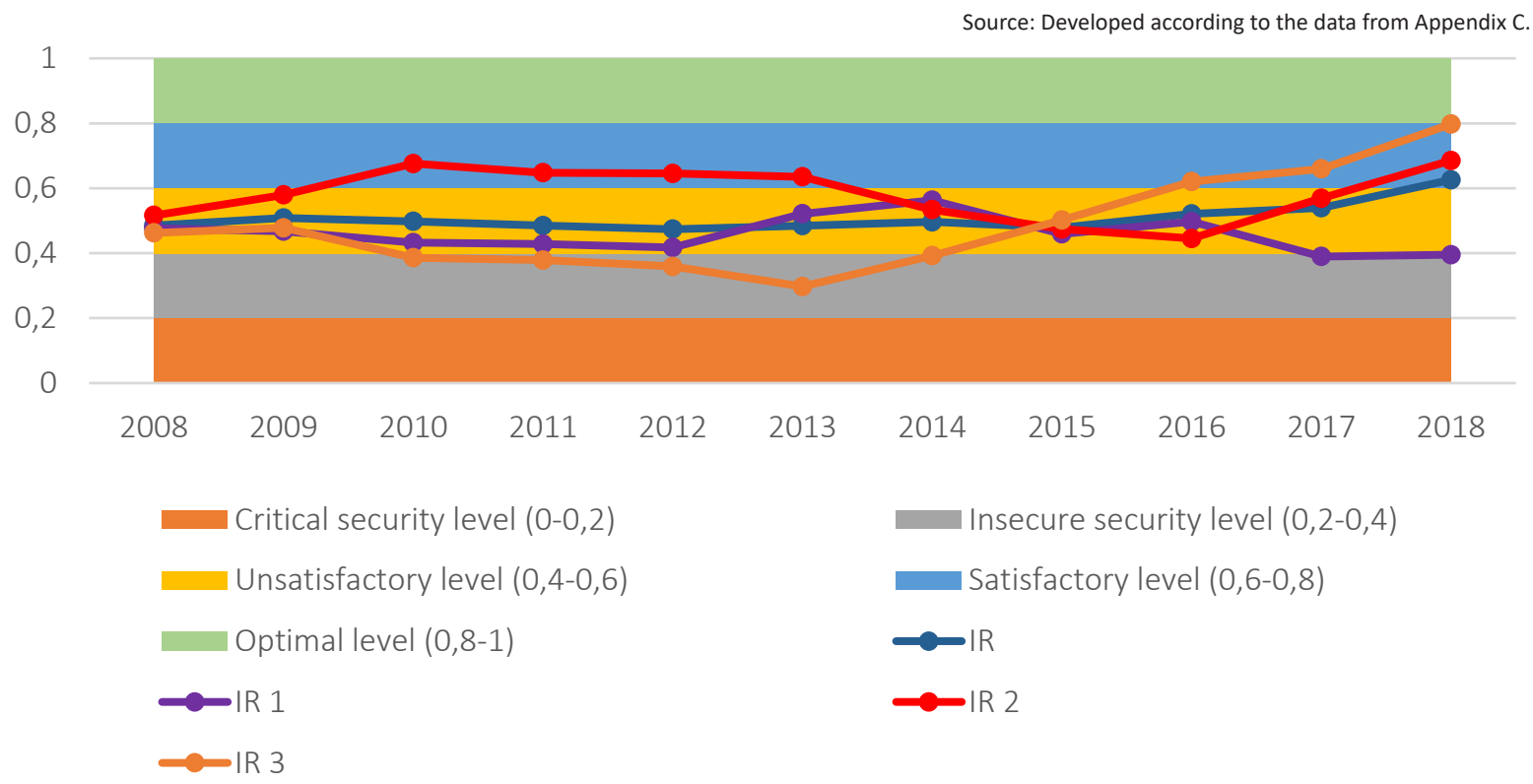

Figure 1. Dynamics of indicators by components (IR1-IR3) and an integrated indicator of Ukrainian banking sector's financial security (IR) in 2014-2018 
Table 2. Matrix of paired correlation coefficients

\begin{tabular}{|c|c|c|c|c|c|c|c|c|c|c|}
\hline & FR1 & FR2 & FR3 & FR4 & FR5 & FR6 & FR7 & FR8 & FR9 & FR10 \\
\hline \multirow{2}{*}{ IR } & 0.65 & -0.54 & -0.15 & 0.61 & 0.53 & -0.77 & -0.46 & -0.65 & -0.77 & 0.79 \\
\hline & FR11 & & FF1 & FF2 & FF3 & FF4 & FF5 & FF6 & FF7 & FF8 \\
\hline \multirow{2}{*}{ IR } & -0.05 & & -0.09 & -0.26 & -0.17 & -0.79 & 0.10 & 0.11 & -0.17 & -0.24 \\
\hline & FF9 & FF10 & FF11 & FF12 & FF13 & FF14 & FF15 & FF16 & FF17 & FF18 \\
\hline \multirow{2}{*}{$\mathbb{I R}$} & 0.69 & 0.19 & 0.61 & -0.33 & 0.12 & 0.40 & 0.40 & -0.29 & 0.38 & 0.13 \\
\hline & FF19 & FF20 & FF21 & FF22 & & ME1 & ME2 & ME3 & ME4 & \\
\hline IR & 0.40 & 0.49 & 0.02 & 0.16 & & 0.82 & 0.12 & 0.43 & 0.30 & \\
\hline
\end{tabular}

Note: Calculated by the authors using the "Correlation" mode of the Excel Data Analysis package.

Table 3. Checking the significance of paired correlation coefficients

\begin{tabular}{l|c|c|c}
\hline \multicolumn{1}{c}{ Indicators } & $t_{\text {emp }}=\frac{r_{B} \sqrt{n-2}}{\sqrt{1-r_{B}^{2}}}$ & Indicators & $t_{\text {emp }}=\frac{r_{B} \sqrt{n-2}}{\sqrt{1-r_{B}^{2}}}$ \\
\hline FR1 & 2.58 & FR10 & 3.90 \\
\hline FR4 & 2.33 & FF4 & -3.88 \\
\hline FR6 & -3.57 & FF9 & 2.85 \\
\hline FR8 & -3.59 & FF11 & 2.28 \\
\hline FR9 & -36 & ME1 & 4.33 \\
\hline
\end{tabular}

Note: Calculated by the authors using the mathematical and statistical functions of the Excel program.

issued to legal entities and individuals, net interest income of banks, insignificant macroeconomic development. It is also advisable for banks to monitor the ratio of non-performing loans to total gross loans, the proportion of liquid assets to total assets, and the rate of a net open position in foreign currency to capital.

\subsection{Behavioral analysis data}

For behavioral analysis, it is proposed to use the following data and analysis system. The most important indicators have been identified regarding internal indicators for assessing the Ukrainian banking sector's financial security. Regarding external indicators, the impact of funds illegally exported from the country's economy is investigated as an interactive external impact index. This money, being part of the state's liquid resources, mostly do not participate in experiments and national statistical samples, and also have an intermittent basis for calculating international monitoring groups (Herkenrath, 2014). It should be noted that the subjects of funds illegally exported from the country's economy use entirely legal forms and methods of banking and business operations. Besides, the use of banking tools allows making non-cash transfers of funds at the request of economic entities or virtual entities of the economy. Indeed, with the advent of digital technologies and the disclosure of bank secrecy (since 2006; The Verkhovna Rada of Ukraine, 2019), the possibility of withdrawing funds outside the participation of banks has increased. Still, the number of banks in Ukraine has significantly decreased. The structure of the banking sector has also undergone significant changes: if at the beginning of 2012 three state-owned banks held $16 \%$ of the system's assets, then in 2017 the share of assets of the four largest state-owned banks increased to 55\%. Funds illegally exported from the country's economy represent a destabilizing movement of capital. The withdrawn funds have a significant impact on the country's economic stability and the global financial system due to the depletion of the state's foreign exchange reserves, reduced tax revenues, and reduced government revenues. They divert finance from public spending and can reduce the capital available for private investment. Illegal flows can also contribute to the reduction of liquidity of assets, low domestic investment activity of citizens. Finally, destabilizing flows leads to a paradigm shift in economic behavior and social management practices (Herkenrath, 2014; IMF, 2018). 
Comparative analysis of the dynamics of all integral estimates for 2008-2016 (Appendix C) with the dynamics of capital "in tax havens" for 20082014 showed that the integral assessment of financial stability indicators of the banking sector strongly correlates with a lag of one year with the size of assets placed in offshore jurisdictions (the correlation coefficient is 0.75 , and with a lag of two years $-(-0.43)$, without a lag $-(-0.30))$. An increase in the amount of funds illegally exported from the economy as offshore assets negatively affects the financial stability of the entire banking sector of Ukraine and contractors of the country's financial institutions from the corporate and household sectors. The negative correlation was broken only in 2013-2014. Despite a decrease in these assets in 2013 compared to 2012, the financial condition in 2015 deteriorated compared to 2014. In 2012, there was a decline in business and economic activity in global markets and a recession in Europe. During 2012-2013, the value of Ukraine's gross external debt increased, but it decreased in 2015-2016. At the beginning of 2015, experts discussed the possible default of Ukraine. The conflict in Eastern Ukraine and the economic downturn also significantly worsened the financial situation at that time. In December 2014 - April 2015, the NBU's foreign exchange reserves fell below USD 9 billion, although the cost of servicing the general public debt in 2015 amounted to USD 3.9 billion. In the structure of the external public debt, the largest share fell on debt on issued securities on the foreign market. In the structure of state-guaranteed external debt, the largest share was due to loans received from international financial organizations (in 2012 and 2015-2016), and loans secured from foreign commercial banks and other foreign financial institutions; in the currency structure of Ukraine's gross external debt, the most significant external borrowings were received in US dollars.

During 2012-2016, the share of gross external debt to GDP increased significantly in every year. Thus, in 2012, the total amount of public debt management expenses amounted to UAH 92.3 billion ( $40.1 \%$ of them are payments on external debt), and in 2015, the state budget expenditures on repayment and servicing of the state debt amounted to UAH 503.4 billion (66.3\% of them are payments on external debt) (The Ministry of Finance of Ukraine, 2020). It becomes clear that the funds illegally exported from the country's economy could provide for the lack of liquid resources that the Ukrainian economy was experiencing at that time. At a minimum, a comparison of the dynamics of the size of withdrawn assets placed in offshore jurisdictions and a partial component of the integral indicator "Financial stability" confirms the supremacy of the first factor over the second one with an hour delay per year. The delay can be explained by the existence of a so-called "social security cushion" in the form of the State budget. Accordingly, in the system of indicators of banking sector's financial security (Appendix A, the "Macroeconomic stability" component), it is necessary to enter an indicator of funds illegally extracted from the country's economy with a lag of +1 year.

\section{DISCUSSION}

Despite a number of studies confirming the importance of calculating the Ukrainian banking sector's financial security level, scientific papers are limited to a list of relevant indicators and their correlation of compliance and results of prudential regulation of banks. Two questions arise: Is the list of factors sufficient to calculate the overall integral indicator? and Can solely static indicators be applied to calculate it in the context of system-deterministic challenges?

Thus, depending on the economic content under the Guidelines for calculating the level of economic security of Ukraine, the set of indicators is divided into three types - stimulants, destimulators, and of mixed type. In this paper, the division of factors is limited to stimulators and destimulators using expert evaluation methods. However, it is advisable to use other classification methods for assigning characteristic values to a certain value of the financial security component indicator. The results obtained in the paper are ambiguous as to the effect of the individual factors on the banking sector's functioning. Nevertheless, they support the discussion about the existence of negative results in the financial sector divergence over the real one. This finding is consistent with Snishchenko (2018) and Subbotovych et al. (2013) that the banking sector's financial stability monitoring results are essential components of monitoring financial 
market participants' performance under the impact of destabilizing factors.

The problem of maintaining the banking sector's resilience in an unstable external environment is addressed by operational analysis of macro-, meso-, and microenvironments, as confirmed by Karkovska et al. (2018). However, there is a tendency and threat of negative impact of system-determined challenges that are either not logical or are new to the Ukrainian banking sector. Such challenges include the consequences of the Pandemic Coronavirus Disease. However, while agreeing with the threat identified by the IMF (IMF, 2018) in the form of illegally exported cash flows, the question of the banking material base of the country's financial operations remains open. Therefore, further practical research on determining the level and calculating the total integral indicator of the Ukrainian banking sector's financial security is promising and necessary to form a set of measures to improve the banking sector's ability to accompany the economic development of the country. This study also considers the argument on the feasibility of using these calculations in the rating and ranking of banks, as methodologically and empirically defined by Wojewodzki et al. (2017), Tarashev et al. (2011), and Marković et al. (2020).

The paper proposes an algorithm for monitoring the Ukrainian banking sector's financial security, which contains three blocks, according to three groups of components. For block 1, to determine the Ukrainian banking sector's financial security, it is proposed to expand the acceptable list of indicators into macroeconomic and highly specialized components of bank sectors' performance. Block 2 provides for determining the most powerful indicators and monitoring their dynamics, using preventive, administrative or market regulators to maintain an acceptable level of Ukrainian banking sector's financial security. If an abnormal level of selected indicators is detected, which are assigned the task of continually monitoring the level of financial security, a decision is made to improve the situation, or radical management mechanisms are applied. Block 3 involves monitoring the factors that influence the most powerful indicators. The paper proposes to add funds illegally withdrawn from the country to these factors. The relationship between the dynamics of the partial component of the integral indicator "Financial stability" and the dynamics of funds illegally removed from the country is revealed. It is believed that in the case of administrative intervention by the Ukrainian government in 2008-2015 to prevent the withdrawal of potential investment capital from Ukraine, it would be possible to avoid the level of the systemic crisis in which the financial system of Ukraine is now.

The possibility of applying the characteristic values of the resulting total Integral Index, according to the delimitation in section 5 of Methodical Recommendations on Calculation of Ukraine's Economic Security Level (2013), is also subject to discussion. Thus, according to the approved ranking in the recommendations and the results obtained in the paper, in 2008-2017 (values of 0.485 , $0.508,0.498,0.485,0.474,0.484,0.496,0.479,0.521$, 0.539 , respectively), the level of banking sector's financial security in Ukraine is assessed as "unsatisfactory", and only in 2018, it reaches the "satisfactory" level (0.626).

Based on the study, it is believed that the financial security of the country's banking sector should be understood as the state of the country's banking system, in which its ability to implement financial, currency, and monetary policies in an unstable external environment is maintained through managerial decisions made based on strategic analysis of macro-, meso- and microenvironment.

\section{CONCLUSION}

The paper calculates the indicator of financial stability of the Ukrainian banking sector's based on the analysis of standardized macroeconomic and industry indicators. The advantage of the set of proposed indicators is to consider the conditions of divergence of the financial sector over the real sector. The results show the level of the banking sector's financial stability using multicomponent analysis. The practical application of the method proposed in the paper allowed establishing the period (2008-2017), after which the Ukrainian economy restored the level of financial security of the banking sector in 
2018. Based on behavioral analysis, the dynamics of the withdrawal of remote assets located in offshore jurisdictions was compared with the partial integral indicator "Financial stability". This allowed determining the influence of the behavioral factor on the efficiency of the banking sector's functioning in Ukraine. Thus, this study forms an applied basis for monitoring the financial security of the country's banking sector and improve the tools for this.

The results will allow the government to adjust banking and monetary policies to form a "safety cushion" for the financial sector and minimize financial threats.

\section{AUTHOR CONTRIBUTIONS}

Conceptualization: Nadiia Yasynska.

Data curation: Oksana Penez.

Formal analysis: Iryna Syrmamiikh.

Funding acquisition: Nadiia Yasynska, Iryna Syrmamiikh, Oksana Penez.

Investigation: Nadiia Yasynska, Iryna Syrmamiikh, Oksana Penez.

Methodology: Nadiia Yasynska, Iryna Syrmamiikh.

Project administration: Nadiia Yasynska, Iryna Syrmamiikh.

Resources: Oksana Penez.

Software: Iryna Syrmamiikh, Oksana Penez.

Supervision: Nadiia Yasynska.

Validation: Nadiia Yasynska, Iryna Syrmamiikh.

Visualisation: Oksana Penez.

Writing - original draft: Nadiia Yasynska, Iryna Syrmamiikh, Oksana Penez.

Writing - reviewing \& editing: Nadiia Yasynska, Iryna Syrmamiikh, Oksana Penez.

\section{REFERENCES}

1. Aguayo, F. Z., \& Ślusarczyk, B. (2020). Risks of Banking Services' Digitalization: The Practice of Diversification and Sustainable Development Goals. Sustainability, MDPI, Open Access Journal, 12(10), 1-10. https://doi. org/10.3390/su12104040

2. Aldasoro, I., Gambacorta, L., Giudici, P., \& Leach T. (2020). Operational and Cyber Risks in the Financial Sector (Monetary and Economic Department. BIS Working Papers No 840). Retrieved from https://www.bis.org/publ/ work840.pdf

3. Baranovsky, O. I. (2004). Financial Security in Ukraine (assessment methodology and support mechanisms). Kyiv: Kyiv National University of Trade and Economics. (In Ukrainian).

4. Berger, A. N., \& Humphrey, D. B. (1997). Efficiency of Financial Institutions: International Survey and Directions for Future Research
(Working Paper No 1997-11).

Washington D.C.: Board of Governors of the Federal Reserve System. Finance and Economics Discussion.

5. Dougherty, C. (2011). Introduction to Econometrics (4th ed.). London: Oxford University Press.

6. Gladkikh, D. M. (2015). Osnovni zahrozy bezpetsi bankivskoyi systemy Ukrainy ta shliakhy yikh podolannia [The Main Threats to the Security of the Banking System of Ukraine and Ways to Overcome Them]. Analitychna zapyska (Viddil finansovoyi bezpeky № 64, Seriya «Ekonomika»). Natsionalnyi instytut stratehichnykh doslidzhen - Analytical note (Financial Security Department № 64, Economics Series). National Institute for Strategic Studies. (In Ukrainian). Retrieved from http:// old2.niss.gov.ua/articles/2125/

7. Gladkikh, D. M. (2019). Zabezpechennia bankivskoi bezpeky
Ukrainy v umovakh rozvytku informatsiynoi ekonomiky [Ensuring Banking Security of Ukraine in Conditions Development of Information Economy]. (Doctoral thesis). Kyiv: NISS. (In Ukrainian). Retrieved from https://niss.gov.ua/ sites/default/files/2020-02/gladkikh_disertacia.pdf

8. Goldberger, A. S. (1991). A Course in Econometrics. Cambridge. Massachusetts: Harvard University Press. Retrieved from https://idoc. pub/documents/goldberger-acourse-in-econometrics-m34mrzp7gzl6

9. Greene, W. H. (2012). Econometric Analysis (7th ed.). New York: New York University, Prentice Hall.

10. Herkenrath, M. (2014). Illicit Financial Flows and their Developmental Impacts: An Overview, International Development Policy. Revue internationale de politique de développement, 5.3. https://doi. org/10.4000/poldev. 1863 
11. International Monetary Fund. (2018). The IMF and the Fight Against Illicit Financial Flows. International Monetary Fund (Press Release). Retrieved from https:// www.imf.org/en/About/Factsheets/ Sheets/2018/10/07/imf-and-thefight-against-illicit-financial-flows

12. Karkovska, V. Ya., ProkopyshynRashkevych. L. M., \& Yakymets, M. M. (2018). Finansova bezpeka bankivskoi systemy: realii ta perspektyvy [Financial Security of the Banking System: Realities and Prospects]. Infrastruktura rynku Market infrastructure, 25, 673-680. (In Ukrainian). Retrieved from http://www.market-infr.od.ua/journals/2018/25_2018_ukr/114.pdf

13. Marković, V., Maksimović, D., \& Gajić, M. (2020). Ranking Banks by Applying the Multilevel I-distance Methodology. Operational Research in Engineering Sciences: Theory and Applications, 3(1), 57-71. https://doi org/10.31181/oresta2001057m

14. Marković, V., Stajić, L., Stević, Ž., Mitrović, G., Novarlić, B., \& Radoji cić, Z. (2020). A Novel Integrated Subjective-Objective MCDM Model for Alternative Ranking in Order to Achieve Business Excellence and Sustainability. Symmetry, 12(1), 164, 1-25. https:// doi.org/10.3390/sym12010164

15. Millar, J. N., Oliner, S. D., \& Sichel D. E. (2016). Time-to-plan Lags for Commercial Construction Projects. Regional Science and Urban Economics, 59(C). 75-89. https://doi.org/10.1016/j.regsciurbeco.2016.05.002

16. Obradović, S., \& Grbić M. (2015). Causality Relationship Between Financial Intermediation by Banks and Economic Growth: Evidence from Serbia. Prague Economic Papers, 24(1), 60-72. https://doi. org/10.18267/j.pep.500

17. Packer, F., \& Tarashev, N. (2011). Rating Methodologies for Banks. BIS Quarterly Review, 2, 39-52. Retrieved from http://ssrn.com/ abstract $=1864706$

18. Siemiątkowski, P. (2017). External Financial Security of the European Union Member States outside the Eurozone. Journal of International Studies, 10(1), 84-95. Retrieved from https://doi.org/10.14254/2071$8330.2017 / 10-4 / 6$

19. Snishchenko, R. G. (2018). Indykatory finansovoi bezpeky yak komponenty monitorynhu uchasnykiv finansovoho rynku. [Financial Security Indicators as Components of Monitoring Financial Market Participants]. Investytsii: praktyka ta dosvid. Seriya: Ekonomichna nauka - Investments: practice and experience. Series: Economics, 3, 9-13. (In Ukrainian). http://www.investplan. com.ua/?op=1\&z=5906\&i=1

20. Subbotovych, Yu., \& Antropova, O. (2013). Indykatory finansovoi bezpeky Ukrainy [Indicators of Financial Security of Ukraine]. Svit finansiv - The world of finance, 2, 144-151. (In Ukrainian). Retrieved from http://dspace.wunu.edu.ua/bit stream/316497/10024/1/\%D0\%A1\% D1\%83\%D0\%B1\%D0\%B1\%D0\%B E\%D1\%82\%D0\%BE\%D0\%B2\%D0 \%B8\%D1\%87\%20\%D0\%AE..pdf

21. The Ministry of Economic Development and Trade of Ukraine. (2013). Pro zatverdzhennia Metodychnykh rekomendatsii shchodo rozrakhunku rivnia ekonomichnoi bezpeky Ukrainy [About the Statement of Methodical Recommendations on Calculation of Ukraine's Economic Security Level]. Order, 1277. (In Ukrainian). Retrieved from https:// zakon.rada.gov.ua/rada/show/ v1277731-13?lang=uk\#Text

22. The Ministry of Finance of Ukraine. (2020). Strategy and Debt Management Program. (In Ukrainian). Retrieved from https://mof.gov.ua/ en/osnovna-informacija

23. The National Bank of Ukraine (2020a). Statistics of Financial Stability Indicators. (In Ukrainian). Retrieved from https://bank.gov.ua/ control/uk/publish/category?cat_ $\mathrm{id}=44575$

24. The National Bank of Ukraine. (2019). Overview of the Banking Sector. (In Ukrainian). Retrieved from https://bank.gov.ua/file/ download?file=Banking_Sector_Review_2019-08.pdf

25. The National Bank of Ukraine. (2020). International Reserves. (In Ukrainian). Retrieved from https:// bank.gov.ua/statistic/sdds/sdds-data
26. The State Statistics Service of Ukraine. (2020). Retrieved from http://www.ukrstat.gov.ua/ (In Ukrainian).

27. The State Treasury Service of Ukraine. (2020a). Retrieved from http://www.treasury.gov.ua/main/ uk/index (In Ukrainian).

28. The Verkhovna Rada of Ukraine. (2019). Pro zatverdzhennia Seredniostrokovoi stratehii upravlinnia derzhavnym borhom na 2019-2022 roky [On Approval of the MediumTerm Public Debt Management Strategy for 2019-2022]. Resolution of the Cabinet of Ministers of Ukraine, 473. (In Ukrainian). Retrieved from https://zakon.rada.gov.ua/laws/ show/473-2019-\%D0\%BF\#Text

29. Tobias, A. (2020). Monetary and Financial Stability during the Coronavirus Outbreak. International Monetary Fund. (Press Release). Retrieved from https://blogs.imf. org/2020/03/11/monetary-andfinancial-stability-during-the-coronavirus-outbreak/

30. Vasylchyshyn, O. B. (2017). Financial Security of the Banking System of Ukraine: Philosophical Determinants. Ternopil: Ternopil National Economic University. (In Ukrainian).

31. Vlasyuk, O. S. (2014). Actual Problems of Financial Security of Ukraine in the Conditions of Post-crisis Transformation. Kyiv: NISD. (In Ukrainian).

32. Vu, H. L., Wai Ng, K. T., \& Bolingbroke, D. (2019). Time-lagged Effects of Weekly Climatic and Socio-economic Factors on ANN Municipal Yard Waste Prediction Models. Waste Management, 84. 129-140. https://doi.org/10.1016/j. wasman.2018.11.038

33. Wojewodzki, M, Poon, W. P. H., \& Shen, J. (2018). The Role of Credit Ratings on Capital Structure and its Speed of Adjustment: an International Study. European Journal of Finance, 24(9), 735-760. https://doi.or g/10.1080/1351847X.2017.1354900

34. Zachosova, N., \& Babina, N. (2018). Identification of Threats to Financial Institutions' Economic Security as an Element of the State Financial Security Regulation. Baltic Journal of Economic Studies, 4(3), 80-87. https://doi.org/10.30525/22560742/2018-4-3-80-87 


\section{APPENDIX A}

Table A1. System of indicators for evaluating the Ukrainian banking sector's financial security

Source: Grouped and supplemented according to Karkovska et al. (2018), Snishchenko (2018), Subbotovych et al. (2013), Zachosova et al. (2018), Overview of the banking sector by NBU (2020).

\begin{tabular}{|c|c|c|}
\hline Component & Key safety indicators & Index symbols \\
\hline \multirow{11}{*}{ Financial results } & Total assets & $\mathrm{FR}_{1}$ \\
\hline & Gross loans to business entities & $\mathrm{FR}_{2}$ \\
\hline & Gross loans to individuals & $\mathrm{FR}_{3}$ \\
\hline & Funds of business entities & $\mathrm{FR}_{4}$ \\
\hline & Funds of individuals & $\mathrm{FR}_{5}$ \\
\hline & Gross loans to business entities / GDP & $\mathrm{FR}_{6}$ \\
\hline & Gross loans to individuals / GDP & $\mathrm{FR}_{7}$ \\
\hline & Funds of business entities / GDP & $\mathrm{FR}_{8}$ \\
\hline & Funds of individuals / GDP & $\mathrm{FR}_{9}$ \\
\hline & Net interest income & $\mathrm{FR}_{10}$ \\
\hline & Deductions to reserves & $\mathrm{FR}_{11}$ \\
\hline \multirow{22}{*}{ Financial stability } & The ratio of regulatory capital to risk-weighted assets & $\mathrm{FF}_{1}$ \\
\hline & The ratio of regulatory capital of the first level to risk-weighted assets & $\mathrm{FF}_{2}$ \\
\hline & The ratio of non-performing loans net of provisions to capital & $\mathrm{FF}_{3}$ \\
\hline & Ratio of non-performing loans to total gross loans & $\mathrm{FF}_{4}$ \\
\hline & Ratio of net income to average total assets (return on assets) & $\mathrm{FF}_{5}$ \\
\hline & Ratio of net income to average capital (return on capital) & $\mathrm{FF}_{6}$ \\
\hline & Ratio of interest margin to gross income & $\mathrm{FF}_{7}$ \\
\hline & Ratio of non-interest expenses to gross income & $\mathrm{FF}_{8}$ \\
\hline & Ratio of liquid assets to total assets & $\mathrm{FF}_{9}$ \\
\hline & Ratio of liquid assets to short-term liabilities & $\mathrm{FF}_{10}$ \\
\hline & Ratio of net open position in foreign currency by capital & $\mathrm{FF}_{11}$ \\
\hline & The ratio of capital to assets & $\mathrm{FF}_{12}$ \\
\hline & Large risk-to-capital ratio & $\mathrm{FF}_{13}$ \\
\hline & The ratio of gross position in financial derivatives from the asset to capital & $\mathrm{FF}_{14}$ \\
\hline & The ratio of gross position in financial derivatives on the liability side to the capital & $\mathrm{FF}_{15}$ \\
\hline & Ratio of profit (loss) on financial instruments to gross income & $\mathrm{FF}_{16}$ \\
\hline & Ratio of staff costs to non-interest expenses & $\mathrm{FF}_{17}$ \\
\hline & The spread between the interest rates on loans and deposits & $\mathrm{FF}_{18}$ \\
\hline & Spread between the highest and lowest interbank rates & $\mathrm{FF}_{19}$ \\
\hline & Ratio of customer deposits to total gross loans (other than interbank loans) & $\mathrm{FF}_{20}$ \\
\hline & Ratio of foreign currency loans to total gross loans & $\mathrm{FF}_{21}$ \\
\hline & Ratio of foreign currency liabilities to total liabilities & $\mathrm{FF}_{22}$ \\
\hline \multirow{4}{*}{ Macroeconomic stability } & Gross domestic product & $\mathrm{ME}_{1}$ \\
\hline & Inflation rate & $\mathrm{ME}_{2}$ \\
\hline & NBU discount rate & $\mathrm{ME}_{3}$ \\
\hline & External debt of Ukraine & $\mathrm{ME}_{4}$ \\
\hline
\end{tabular}


Source: An improved methodology stated by Baranovskyy (2004), Karkovska et al. (2018), Snishchenko (2018), Subbotovych et al. (2013), Vasylchyshyn (2017), Vlasyuk (2014).

Block 1.

Determination of the total integral indicator

The component "Financial stability": $I R_{2}=\overline{F F_{i}}$
The component "Financial results": 


\section{APPENDIX B}

Table B1. Performance system of the "Financial results" component

\begin{tabular}{|c|c|c|c|c|c|c|c|c|c|c|c|c|c|}
\hline & & & & & & & : C & ed a & ling $\mathrm{t}$ & e data o & he Nat & al Bank & Ukrai \\
\hline Factors & Unit & $\begin{array}{l}\text { A kind of II on the } \\
\text { level of impact on } \\
\text { the system - } \\
\text { the object of study }\end{array}$ & 2008 & 2009 & 2010 & 2011 & 2012 & 2013 & 2014 & 2015 & 2016 & 2017 & 2018 \\
\hline $\mathrm{FR}_{1}$ & $\begin{array}{l}\text { UAH } \\
\text { bln }\end{array}$ & Stimulator & 967 & 1,002 & 1,090 & 1,212 & 1,264 & 1,409 & 1,477 & 1,571 & 1,737 & 1,848 & 1,911 \\
\hline $\mathrm{FR}_{2}$ & $\begin{array}{l}\text { UAH } \\
\text { bln }\end{array}$ & Destimulator & 476 & 498 & 537 & 608 & 634 & 727 & 820 & 831 & 847 & 870 & 919 \\
\hline $\mathrm{FR}_{3}$ & $\begin{array}{l}\text { UAH } \\
\text { bln }\end{array}$ & & 273 & 236 & 205 & 197 & 184 & 189 & 209 & 176 & 157 & 171 & 197 \\
\hline $\mathrm{FR}_{4}$ & $\begin{array}{l}\text { UAH } \\
\text { bln }\end{array}$ & & 162 & 128 & 160 & 205 & 221 & 258 & 283 & 349 & 413 & 427 & 430 \\
\hline $\mathrm{FR}_{5}$ & $\begin{array}{l}\text { UAH } \\
\text { bln }\end{array}$ & & 219 & 214 & 276 & 312 & 368 & 443 & 403 & 402 & 437 & 479 & 509 \\
\hline $\mathrm{FR}_{6}$ & $\%$ & & 48.0 & 52.6 & 47.9 & 45.1 & 43.4 & 47.7 & 51.7 & 41.8 & 35.5 & 29.2 & 25.8 \\
\hline $\mathrm{FR}_{\text {}}$ & $\%$ & Stimulators & 27.5 & 24.9 & 18.3 & 14.6 & 12.6 & 12.4 & 13.1 & 8.8 & 6.6 & 5.7 & 5.5 \\
\hline $\mathrm{FR}_{8}$ & $\%$ & & 16.4 & 13.5 & 14.3 & 15.2 & 15.1 & 17.0 & 17.8 & 17.6 & 17.3 & 14.3 & 12.1 \\
\hline $\mathrm{FR}_{9}$ & $\%$ & & 22.1 & 22.6 & 24.6 & 23.1 & 25.2 & 29.1 & 25.4 & 20.2 & 18.3 & 16.1 & 14.3 \\
\hline $\mathrm{FR}_{10}$ & $\begin{array}{l}\text { UAH } \\
\text { bln }\end{array}$ & & 37.2 & 54.5 & 51.9 & 53.8 & 49.2 & 49.1 & 52.2 & 39.1 & 44.2 & 53.1 & 73.0 \\
\hline $\mathrm{FR}_{11}$ & $\begin{array}{l}\text { UAH } \\
\text { bln }\end{array}$ & & 24.0 & 75.4 & 46.2 & 36.5 & 22.3 & 28.0 & 84.4 & 114.5 & 198.3 & 49.3 & 23.8 \\
\hline
\end{tabular}

Table B2. System of indicators of the "Financial stability" component

Source: Systematized according to the data from the National Bank of Ukraine.

\begin{tabular}{|c|c|c|c|c|c|c|c|c|c|c|c|c|}
\hline Factors & $\begin{array}{c}\text { A kind of Il on the } \\
\text { level of impact on the } \\
\text { system - the object of } \\
\text { study }\end{array}$ & 2008 & 2009 & 2010 & 2011 & 2012 & 2013 & 2014 & 2015 & 2016 & 2017 & 2018 \\
\hline $\mathrm{FF}_{1 \ldots}$ & \multirow{2}{*}{ Stimulators } & 14.01 & 18.08 & 20.83 & 18.90 & 18.06 & 18.26 & 15.6 & 12.31 & 12.69 & 16.1 & 16.18 \\
\hline $\mathrm{FF}_{2}$ & & 11.15 & 14.23 & 15.11 & 13.99 & 13.77 & 13.89 & 11.21 & 8.3 & 8.96 & 12.12 & 10.52 \\
\hline $\mathrm{FF}_{3}$ & \multirow{2}{*}{ Destimulators } & 9.16 & 31.97 & 29.17 & 25.76 & 36.03 & 30.65 & 61.07 & 129.02 & 89.37 & 70.18 & 60.2 \\
\hline $\mathrm{FF}_{4}$ & & 3.88 & 13.70 & 15.27 & 14.73 & 16.54 & 12.89 & 18.98 & 28.03 & 30.47 & 54.54 & 52.85 \\
\hline $\mathrm{FF}_{5}$ & \multirow{3}{*}{ Stimulators } & 1.46 & -4.42 & -1.46 & -0.65 & 0.48 & 0.26 & -4.24 & -5.54 & -12.47 & -1.76 & 1.6 \\
\hline $\mathrm{FF}_{6}$ & & 11.96 & -33.71 & -10.29 & -4.44 & 3.26 & 1.72 & -31.95 & -65.51 & -122.2 & -15.34 & 14.61 \\
\hline $\mathrm{FF}_{7}$ & & 51.16 & 66.76 & 65.98 & 63.07 & 64.15 & 58.56 & 48.46 & 39 & 45.94 & 50.2 & 52.02 \\
\hline $\mathrm{FF}_{8}$ & Destimulator & 52.95 & 61.08 & 61.89 & 68.26 & 61.45 & 65.95 & 59.85 & 54.4 & 60.91 & 76.14 & 61.92 \\
\hline $\mathrm{FF}_{9}$ & \multirow{4}{*}{ Stimulators } & 9.35 & 11.45 & 18.84 & 18.65 & 22.15 & 20.63 & 26.4 & 33 & 48.53 & 53.94 & 51.14 \\
\hline $\mathrm{FF}_{10}$ & & 32.99 & 35.88 & 91.19 & 94.73 & 90.28 & 89.11 & 86.14 & 92.87 & 92.09 & 98.37 & 93.52 \\
\hline $\mathrm{FF}_{11}$ & & 33.10 & 28.51 & 21.61 & 8.41 & 2.50 & 6.94 & 31.69 & 136.03 & 118.88 & 89.61 & 134.77 \\
\hline $\mathrm{FF}_{12 \ldots}$ & & 12.86 & 13.10 & 14.63 & 14.76 & 15.03 & 15.06 & 11.23 & 8.02 & 9.78 & 11.9 & 10.77 \\
\hline $\mathrm{FF}_{13}$ & \multirow{3}{*}{ Destimulators } & 187.36 & 169.21 & 161.21 & 164.46 & 172.91 & 172.05 & 250.04 & 364.14 & 308.27 & 208.31 & 176.23 \\
\hline $\mathrm{FF}_{14}$ & & 0.38 & 0.03 & 0.33 & 1.13 & 1.25 & 1.3 & 2.83 & 12.55 & 36.81 & 35.21 & 0.22 \\
\hline $\mathrm{FF}_{15}$ & & 0.27 & 0.04 & 0.04 & 0.10 & 0.09 & 0.13 & 0.27 & 0.19 & 0.19 & 0.07 & 0.04 \\
\hline $\mathrm{FF}_{16}$ & Stimulator & 16.46 & 4.45 & 3.22 & 5.12 & 3.71 & 3.83 & 14.26 & 21.1 & 8.97 & 7 & 4.16 \\
\hline $\mathrm{FF}_{17}$ & \multirow{3}{*}{ Destimulators } & 48.13 & 40.67 & 40.73 & 38.91 & 41.32 & 41.04 & 35.48 & 36.14 & 34.53 & 32.11 & 37.06 \\
\hline $\mathrm{FF}_{18}$ & & 816 & 586 & 721 & 567 & 485 & 383 & 540 & 772 & 600 & 681 & 525 \\
\hline $\mathrm{FF}_{19}$ & & 2,753 & 2,499 & 1,790 & 2,900 & 4,494 & 6,490 & 4,660 & 2,401 & 1,384 & 2,450 & 2,050 \\
\hline $\mathrm{FF}_{20}$ & \multirow{2}{*}{ Stimulators } & 48.36 & 45.27 & 56.01 & 61.19 & 69.80 & 73.34 & 64.45 & 71.22 & 80.51 & 84.59 & 81.83 \\
\hline $\mathrm{FF}_{21}$ & & 60.32 & 52.59 & 48.23 & 42.13 & 37.66 & 34.72 & 47.77 & 57.9 & 51.35 & 47.05 & 46.52 \\
\hline $\mathrm{FF}_{22}$ & Destimulator & 59.04 & 55.83 & 51.25 & 49.76 & 49.22 & 43.25 & 49.27 & 52.82 & 55.92 & 52.81 & 46.9 \\
\hline
\end{tabular}


Table B3. System of indicators of the "Macroeconomic stability" component

Source: Systematized according to the National Bank of Ukraine, the Ministry of Finance of Ukraine, the State Treasury Service of Ukraine and the State Statistics Service of Ukraine.

\begin{tabular}{|c|c|c|c|c|c|c|c|c|c|c|c|c|c|}
\hline Factors & Unit & $\begin{array}{c}\text { A kind of II on the } \\
\text { level of impact on the } \\
\text { system - the object } \\
\text { of study }\end{array}$ & 2008 & 2009 & 2010 & 2011 & 2012 & 2013 & 2014 & 2015 & 2016 & 2017 & 2018 \\
\hline ME1 & UAH bln & Stimulator & 948,056 & 913,345 & $1,082,569$ & $1,316,600$ & $1,408,899$ & $1,454,931$ & $1,566,728$ & $1,979,458$ & $2,383,182$ & $2,982,900$ & $3,558,706$ \\
\hline ME2 & UAH bln & Destimulator & 122.3 & 112.3 & 109.1 & 104.6 & 99.8 & 100.5 & 124.9 & 143.3 & 112.4 & 113.7 & 109.8 \\
\hline ME3 & UAH bln & Stimulator & 12 & 10.25 & 7.75 & 7.75 & 7.5 & 6.5 & 14 & 22 & 14 & 14.5 & 18 \\
\hline ME4 & UAH bln & Destimulator & 101,743 & 103,432 & 117,346 & 126,236 & 134,625 & 142,079 & 125,297 & 117,668 & 112,524 & 115,451 & 114,710 \\
\hline
\end{tabular}




\section{APPENDIX C}

Table C1. Standardized values of indicators of the components, partial integral indicators $\left(I R_{1}, I R_{2}, I R_{3}\right)$ and total integrated indicator (IR)

\begin{tabular}{|c|c|c|c|c|c|c|c|c|c|c|c|}
\hline Factors & 2008 & 2009 & 2010 & 2011 & 2012 & 2013 & 2014 & 2015 & 2016 & 2017 & 2018 \\
\hline FR1 & 0.00 & 0.04 & 0.13 & 0.26 & 0,31 & 0.47 & 0.54 & 0.64 & 0.82 & 0.93 & 1.00 \\
\hline FR2 & 1.00 & 0.95 & 0.86 & 0.70 & 0.64 & 0.43 & 0.22 & 0.20 & 0.16 & 0.11 & 0.00 \\
\hline FR3 & 1.00 & 0.68 & 0.41 & 0.34 & 0.23 & 0.27 & 0.44 & 0.16 & 0.00 & 0.12 & 0.34 \\
\hline FR4 & 0.11 & 0.00 & 0.11 & 0.26 & 0.31 & 0.43 & 0.51 & 0.73 & 0.94 & 0.99 & 1.00 \\
\hline FR5 & 0.02 & 0.00 & 0.21 & 0.33 & 0.52 & 0.78 & 0.64 & 0.64 & 0.76 & 0.90 & 1.00 \\
\hline FR6 & 0.83 & 1.00 & 0.82 & 0.72 & 0.66 & 0.82 & 0.97 & 0.60 & 0.36 & 0.13 & 0.00 \\
\hline FR7 & 1.00 & 0.88 & 0.58 & 0.41 & 0.32 & 0.31 & 0.34 & 0.15 & 0.05 & 0.01 & 0.00 \\
\hline FR8 & 0.76 & 0.25 & 0.39 & 0.55 & 0.53 & 0.86 & 1.00 & 0.97 & 0.91 & 0.39 & 0.00 \\
\hline FR9 & 0.53 & 0.56 & 0.70 & 0.59 & 0.74 & 1.00 & 0.75 & 0.40 & 0.27 & 0.12 & 0.00 \\
\hline FR10 & 0.00 & 0.48 & 0.41 & 0.46 & 0.34 & 0.33 & 0.42 & 0.05 & 0.20 & 0.44 & 1.00 \\
\hline FR11 & 0.01 & 0.30 & 0.14 & 0.08 & 0.00 & 0.03 & 0.35 & 0.52 & 1.00 & 0.15 & 0.01 \\
\hline $\mathrm{IR}_{1}$ & 0.48 & 0.47 & 0.43 & 0.43 & 0.42 & 0.52 & 0.56 & 0.46 & 0.50 & 0.39 & 0.40 \\
\hline FF1 & 0.20 & 0.68 & 1.00 & 0.77 & 0.67 & 0.70 & 0.39 & 0.00 & 0.04 & 0.44 & 0.45 \\
\hline FF2 & 0.42 & 0.87 & 1.00 & 0.84 & 0.80 & 0.82 & 0.43 & 0.00 & 0.10 & 0.56 & 0.33 \\
\hline FF3 & 1.00 & 0.81 & 0.83 & 0.86 & 0.78 & 0.82 & 0.57 & 0.00 & 0.33 & 0.49 & 0.57 \\
\hline FF4 & 1.00 & 0.81 & 0.78 & 0.79 & 0.75 & 0.82 & 0.70 & 0.52 & 0.48 & 0.00 & 0.03 \\
\hline FF5 & 0.99 & 0.57 & 0.78 & 0.84 & 0.92 & 0.90 & 0.58 & 0.49 & 0.00 & 0.76 & 1.00 \\
\hline FF6 & 0.98 & 0.65 & 0.82 & 0.86 & 0.92 & 0.91 & 0.66 & 0.41 & 0.00 & 0.78 & 1.00 \\
\hline FF7 & 0.44 & 1.00 & 0.97 & 0.87 & 0.91 & 0.70 & 0.34 & 0.00 & 0.25 & 0.40 & 0.47 \\
\hline FF8 & 1.00 & 0.65 & 0.61 & 0.34 & 0.63 & 0.44 & 0.70 & 0.94 & 0.66 & 0.00 & 0.61 \\
\hline FF9 & 0.00 & 0.05 & 0.21 & 0.21 & 0.29 & 0.25 & 0.38 & 0.53 & 0.88 & 1.00 & 0.94 \\
\hline FF10 & 0.00 & 0.04 & 0.89 & 0.94 & 0.88 & 0.86 & 0.81 & 0.92 & 0.90 & 1.00 & 0.93 \\
\hline FF11 & 0.23 & 0.19 & 0.14 & 0.04 & 0.00 & 0.03 & 0.22 & 1.00 & 0.87 & 0.65 & 0.99 \\
\hline FF12 & 0.69 & 0.72 & 0.94 & 0.96 & 1.00 & 1.00 & 0.46 & 0.00 & 0.25 & 0.55 & 0.39 \\
\hline FF13 & 0.87 & 0.96 & 1.00 & 0.98 & 0.94 & 0.95 & 0.56 & 0.00 & 0.28 & 0.77 & 0.93 \\
\hline FF14 & 0.00 & 1.00 & 1.00 & 0.74 & 0.78 & 0.61 & 0.00 & 0.35 & 0.35 & 0.87 & 1.00 \\
\hline FF15 & 0.00 & 1.00 & 1.00 & 0.74 & 0.78 & 0.61 & 0.00 & 0.35 & 0.35 & 0.87 & 1.00 \\
\hline FF16 & 0.74 & 0.07 & 0.00 & 0.11 & 0.03 & 0.03 & 0.62 & 1.00 & 0.32 & 0.21 & 0.05 \\
\hline FF17 & 0.00 & 0.47 & 0.46 & 0.58 & 0.43 & 0.44 & 0.79 & 0.75 & 0.85 & 1.00 & 0.69 \\
\hline FF18 & 0.00 & 0.53 & 0.22 & 0.58 & 0.76 & 1.00 & 0.64 & 0.10 & 0.50 & 0.31 & 0.67 \\
\hline FF19 & 0.73 & 0.78 & 0.92 & 0.70 & 0.39 & 0.00 & 0.36 & 0.80 & 1.00 & 0.79 & 0.87 \\
\hline $\mathrm{FF} 20$ & 0.08 & 0.00 & 0.27 & 0.40 & 0.62 & 0.71 & 0.49 & 0.66 & 0.90 & 1.00 & 0.93 \\
\hline FF21 & 1.00 & 0.70 & 0.53 & 0.29 & 0.11 & 0.00 & 0.51 & 0.91 & 0.65 & 0.48 & 0.46 \\
\hline$F F 22$ & 0.00 & 0.20 & 0.49 & 0.59 & 0.62 & 1.00 & 0.62 & 0.39 & 0.20 & 0.39 & 0.77 \\
\hline $\mathrm{IR}_{2}$ & 0.52 & 0.58 & 0.68 & 0.65 & 0.65 & 0.64 & 0.53 & 0.47 & 0.45 & 0.57 & 0.69 \\
\hline ME1 & 0.01 & 0.00 & 0.06 & 0.15 & 0.19 & 0.20 & 0.25 & 0.40 & 0.56 & 0.78 & 1.00 \\
\hline ME2 & 0.48 & 0.71 & 0.79 & 0.89 & 1.00 & 0.98 & 0.42 & 0.00 & 0.71 & 0.68 & 0.77 \\
\hline ME3 & 0.35 & 0.24 & 0.08 & 0.08 & 0.06 & 0.00 & 0.48 & 1.00 & 0.48 & 0.52 & 0.74 \\
\hline ME4 & 1.00 & 0.96 & 0.61 & 0.39 & 0.18 & 0.00 & 0.42 & 0.61 & 0.73 & 0.66 & 0.68 \\
\hline $\mathrm{IR}_{3}$ & 0.46 & 0.48 & 0.39 & 0.38 & 0.36 & 0.30 & 0.39 & 0.50 & 0.62 & 0.66 & 0.80 \\
\hline IR & 0.485 & 0.508 & 0.498 & 0.485 & 0.474 & 0.484 & 0.496 & 0.479 & 0.521 & 0.539 & 0.626 \\
\hline
\end{tabular}

Note: Calculated by the authors based on Tables B1-3 of Appendix B. 